\title{
How Co-creating Enhances the Quality of a Brand-consumer Relationship, using the U\&G Approach: The Coca-Cola Case
}

\author{
Nedra Bahri Ammari and Emna Jaziri \\ Université de Carthage, IHEC Présidence, Laboratoire de Recherche en Marketing, \\ Carthage, Tunisie
}

Correspondence should be addressed to: Emna Jaziri; jaziriamna@gmail.com

Received date: 29 March 2016; Accepted date: 17 May 2016; Published date: 7 September 2016

Academic Editor: Imen Fourati Daoud

Copyright (C 2016. Nedra Bahri Ammari and Emna Jaziri . Distributed under Creative Commons CCBY 4.0

\begin{abstract}
The concept of co-creation or value creation has been the subject of several research studies. While the concept of co-creation seems recent, Badot and Cova (1995) have developed it a while ago, in the early 1990s. Despite the thorough discussions about the strategic consequences of the concept of co-creation of value, the cognitive, affective and conative mechanisms of the motivating factors for co-creation still lack investigations. To remedy that omission in literature, we propose in this study to determine the motivating factors that involve the consumer in a co-creation activity focusing on its impact, loyalty and customer retention. Thus, our research introduced a new relationship of $U$ \& $G$ approach to the concept of the joint value creation, which, to our knowledge, has never been the subject of empirical or theoretical study. A questionnaire was developed and distributed via Google Drive to the consumers and users of our chnia tarbijtek -"what's your nickname"- study produced by Coca- Cola proposed application. 360 questionnaires were completed and a structural equation (SEM) with AMOS was used to test the hypothesis. The results show that the social and personal integration affects the online co-creation positively, while learning gives the opposite result. Co-creation affects the strength of the relationship, trust and the satisfaction of both customers and consumers positively as well. The final product shows that loyalty is to a further extent linked to the strength of the relationship between the producer and the consumer.
\end{abstract}

Keywords: co-creation, U \& G approach, personal and social integration, learning, strength of relationship,

Cite this Article as: Nedra Bahri Ammari and Emna Jaziri (2016), " How Co-creating Enhances the nuality of a Rrand-roncumer Relationchin wcino the IIR,F Annrnarh. The Cora-Cola Cace " Inurnal of 


\section{Introduction}

The revolution in the new information and communications technologies (ICT) field has contributed to the development of a new era of customers' empowerment. Every concept frequently defined as marketing reinvention actually corresponds to a new revolution. It is true that at the time of Marketing 2.0, companies have considered consumers, and especially their values. Their desires, needs and feelings were at the heart of managerial concerns. It is indeed within this new generation marketing that the subject of interest is located and perfectly suits to current issues, what is known as co-creation. Nowadays, more and more companies are trying to follow the trend, by actively integrating their customers in their new products and services development processes, Romero, Constantine's and Brünink, (2014). This case of technical marketing, dim but frequent, uses the Internet to create content: co-creation online.

Co-creation is the process by which companies, their partners and the final consumer jointly develop products, services and experiences, leading to a new space where the value created would be shared (Ramaswamy, 2009). This form of cooperation has increased with the technological advances (ICT) (Neuhofer et al., 2013) which promoted the development of social networks, blogs, forums and creative platforms. Thanks to these new interconnected tools for socialization, customers can now actively contribute to the development of new products, ideas and concepts (Hoyer et al., 2010; Nambisan, 2002; Ogawa and Piller, 2006). The companies did realize it and saw it as an opportunity. Upstreaming or down streaming the value chain, or cocreating along with the costumers, who could be experts (lead users) or mere users (emergent nature) represent the key to unlock new sources of competitive advantages for brands (Hoyer et al., 2010; Ogawa and Piller, 2006; Prahalad, 2004; Nambisan, 2002). By having access to brands' platforms, the customers could share their opinions and experiences concerning the product. They could also discuss freely and participate in the evolution of the company's offer and develop its image and reputation. Thus, some brands have found the way to keep their customers loyal while reducing the risks associated with creating a new product or service (Romero et al., 2014; Ramaswamy, 2009). The eYeka platform is a good illustration that allows consumers and major brands to collaborate on creative projects and give in return an amount of money to the winning project. Indeed, a study of Rajah et al., (2012) adopted a positivist attitude to study the influence of co-creation of nomological net marketing results. In addition, this study will examine the causal pathways between the co-creation and trust and the cocreation and strength of the relationship, two paths postulated in theory but not yet tested. Furthermore, the contributions of the study will provide empirical support for the influence of co-creation on downstream construction marketing results. To this end, we are going to inquire about the benefits of the customer's experience of co-creation with a company. We will go beyond the benefits in terms of innovation, reputation and product tests. We will also examine the customer's motives that induced him to engage in a cocreative experience. The theoretical foundations lead us to determine the motivating factors involving the consumer in a co-creation activity. These foundations focus on the impact of the factors on loyalty and retention of the customer in the Tunisian context.

The first part of this work will be devoted to a literature review on the determinants and consequences of co-creation in the industrial context. The second part will present the results of the confirmatory analysis conducted among 360 consumers. The conclusion will be a discussion of the results and the managerial implications of this study. 


\section{Theoretical Background}

\section{Motivations}

In the virtual world, the Uses and Gratifications approach (U \& G) seems to be the most useful and relevant one to explain the different existing patterns that push current customers to participate in online co-creation activities (Romero et al., 2014). According to the $U$ \&G approach, customers' benefits coming from the use of media are split into two dimensions: cognitive and affective (kietzmann, 2011). The former is related to the benefits that customers expect to receive in exchange for their participation (Nambisan, and Baron, 2007; Urista et al., 2008), while the latter is associated with positive and negative feelings generated by the clients during their online interaction with the brand. This could eventually affect the attitudes and feelings of customers towards the company (Nambisan and Baron, 2007; Urista et al., 2008). Joining and participating in communities offer several benefits to the customers such as the exchange of information and / or emotional support (Thurau et al., 2004). Other customers are motivated by financial factors (profit or gain), whereas some others by social factors (Social benefits of Co-Creation) such as social esteem, civism, and networking (Nambisan and Baron, 2009).

\section{Learning benefits}

Some may be motivated by the desire to acquire technological knowledge (product/service) by participating in forums and groups led by the manufacturer. These customers could participate in the co-creation process for knowledge enrichment purposes. Creative activities of Co-Creation reinforce intrinsic motivation and the sense of self-expression and pride (Csikszentmihalyi, 1996; Etgar, 2008). Other studies express different motives, but they can all be classified as the predecessors of the U\&G approach (Luo, 2002; Nambisan and Baron, 2007; Fuller et al., 2010). Social and personal integration trigger different motives as well.

\section{Social integration}

another form of consented client services when participating in cooperative online creating activities based on relational and social ties, created while developing together new products and services with other customers and/or employees of the company on social media platforms.

Due to the close interaction with other individuals, customers could develop a sense of belonging to the online community, they feel involved in the cocreation process and gain a social identity, both outcomes are perceived as benefits (Hoyer et al., 2010; Nambisan and Baron, 2009; Nambisan and Baron, 2007).

\section{Personal integration}

Self-efficiency and the pursuit of community's status could represent a different kind of value for customer benefits. By participating in online cocreation processes, customers can generate a higher sense of self-efficiency: they contribute into innovative processes of the company from the expansion of the customer product-related knowledge and enhance his/her problem-solving skills.

By generating new ideas with high potential, customers could gain a reputation and a status of great influence, leading to the improvement of the state, credibility and self-efficiency (Nambisan and Baron, 2007) related to expertise (Nambisan and Baron, 2009).

\section{Satisfaction}

Customer satisfaction is defined as the extent to which the service provided continues to meet customer expectations (Delgado-Ballester and Munuera-Aleman, 2001). In the context of co-creation on service recovery conducted by Dong et al., (2008), the results showed that the customer co-created recovery solution generated higher levels of satisfaction and promoted the will to carry on. According to Vargo et al., (2008), all the research studies to this date confirm that client participation in the value creation process 
is essential for the development of an innovative product or service that could meet the needs of the customers. This result is coherent along with the concept of satisfaction in terms of decision (Heitmann et al., 2007). They postulate that customers feel satisfied or dissatisfied not only with the product but also with the purchase process itself. The satisfaction induced by the decision is associated with the service development process and thus goes beyond the satisfaction. Moreover, Fleming et al., (2003) added that customer engagement generates emotional satisfaction, and emotionally satisfied clients display two levels higher of customer loyalty, successively reducing the switching behavior related to the rational customer satisfaction toward the company (Fleming Coffman and Harter, 2005). According to Kotze and Plessis (2003), co-production is the customer active involvement in service delivery, contributing at the same time to the satisfaction of their own perceptions, quality and value. Thus, it proves to be that when customers are satisfied with their own performance of co-creation, they are willing to spend more money for the service, or to re-buy the product which creates in them a loyal attitude toward the brand or the organization.

\section{Trust}

It is the key element that holds and connects customers and organizations together, making the process of co-creation feasible. It is a bilateral process that requires a shared effort by brands and customers while trying to keep their promises (for instance, the credibility of the construction) and a mutual commitment. In the Co-creation paradigm, increased trust can be supported by the DART process: Dialogue, Access, Risk assessment and Transparency (Prahalad and Ramaswamy, 2004). Others suggest that the strengthening of trust in virtual environments could be facilitated by Jarvenpaa et al., (1998):

(1)A proactive style of actions, (2) the interactions focused on work, (3) optimized teamwork spirit, (4) leadership dynamics, clear goals and roles, (5) frequent interactions (6) and immediate feedback. Thus, the transparency of information in the interaction process remains essential for building trust between brands and consumers in cocreating activity for an effective participation.

Furthermore, Malaviya and Spargo (2002) and Mascarenhas et al., (2004) argue that co-creation generates a high level of trust within the buyer-seller relationship. In that sense, and according to Dwyer and Tanner (2006), trust is "the belief that the word or promise by one party is reliable and that such party will fulfill its obligations in an exchange relationship." Conceptually, it is suggested that a higher degree of customer co-creation generates higher levels of trust between the client and the distributor (Evans and Wolf, 2005; Leadbeater, 2006; Lundkvist and Yaklef 2004; Malaviya and Spargo, 2002; Mascarenhas et al., 2004). Hence, the construction of trust is considered relational.

2.7. The literature refers to "the strength of the relationship" for a further explanation; it is the extent to which a relationship lasts (Barnes and Howlett, 1998; Crosby et al., 1990; Crosby and Stephens, 1987; Kandampully and Duddy, 1999; Liljander, 2000; Zineldin 1999). Hence, the strength of the relationship is often defined as "the measure and degree / breadth of the relationship" (Bove and Johnson, 2001; Shemwell and Cronin, 1995). In consequence, research confirms that a strong relationship is the desired result of building efforts undertaken by the brand (Crosby and Stephens, 1987; Czepiel, 1990; Granovetter, 1973; Jackson, 1985; Williams, 1997). Some researchers limit the definition of the strength of the relationship to measuring the level of trust and customer engagement (Bove and Johnson, 2006; Shemwell and Cronin, 1995; Rajah et al., 2008). Moreover, Egan (2011) considers that the creation of a better value to the customer while involving them in the process is seen as the basis for a long-term relationship development with the users. It should also be mentioned that co-creation through the customization of interactions and customized specific problem-solving 
processes can facilitate more intimate and stronger seller-buyer relationships (Claycomb and Martin, 2001). Evanschitzky et al., (2006), argue that a strong relationship between seller and buyer contributes to customer loyalty. Therefore, interaction and dialogue that arise in cocreation lead to the creation of a strong seller-buyer relationship, which in turn improves customer equity (Kumar et al., 2010; Van Doorn et al., 2010).

\section{Hypothesis and Conceptual Model}

\section{Hypothesis}

\section{Customer benefits: Relationship between motivational factors and co-creation}

According to literature, motivation is a key factor that drives the consumer to participate in a co-creative activity. According to some researchers, what motivates the consumer to do so is either intrinsic or extrinsic motivation or benefit perceived by the customer (the four factors of $U$ \& $G$ approach). We opted to explain the motivational factors that can be linked to learning, social integration and personal integration (benefits of the U \& G theory.) Literature reveals that customers are increasingly eager and curious to expand their knowledge. Therefore, according to these researchers, customers may be more willing to share their knowledge with companies if in return; they could acquire new information that can improve their knowledge and expertise (Hoyer et al., 2010; Nambisan and Baron, 2007). It implies that learning is an important agent to the willingness of customers to participate in co-creation. Hence:

- H1a: Learning has a positive influence on the customer's co-creation.

By engaging in co-creation and post cocreation, according to Hoyer et al., (2010), customers could benefit from social ties with other users or with the brand itself. Thus, the collaboration requires a high degree of interaction and communication. In addition, co-creation with a brand can be reinforced by the need for recognition.
These advantages lead us to the second hypothesis which is:

- H1b: The social integration benefits have a positive influence on co-creation.

Moreover, as previously reported, the benefits mainly include personal credibility, status and trust (Nambisan and Baron, 2007). That is the reason that motivates customers to co-create. Therefore, personal integration services may be identified as a trigger for motivation, enhancing consumer participation in co-creation. Thus, we could assume the following:

- H1c: The personal integration benefits have a significant and positive impact on the co-creation.

Producer Benefits: Relationship between Co-Creation, satisfaction, trust, strength of relationship and brand loyalty

Relationship between co-creation and satisfaction

Empirical studies have investigated the cocreation and its influence on satisfaction and repeated purchase intention (Dong, Evans and Zou, 2008). Others argue that the effects of co-creation on consumers are asymmetrical and induce positive results with perceived quality and satisfaction (Bendapudi and Leone, 2003). In addition, the authors confirmed the hypothesis that the level of customer engagement in value creation influences their satisfaction with the brand, loyalty, and their intention to spend more, (Grissemann and StokburgerSauer, 2012). As a result:

- H2: Co-creation has a positive effect on customer satisfaction with the brand. Relationship between Co-creation and Satisfaction

Several authors argued that a higher degree of co-creation with the customer generates higher levels of trust between the customer and the company (Leadbeater, 2006; Evans and Wolf, 2005). Furthermore, certain research studies show that the co-creation leads to trust between the company and its consumers, 
and trust in its turn contributes to strong links between them (Boyle, 2007; Mascarenhas et al., 2004; Malaviya and Spargo, 2002). The more consumers cocreate, the more their trust level increases. Hence, we come to the following hypothesis:

- H3: Co-creation positively influences the level of trust of the customer towards the brand

Relationship between Satisfaction, Trust and Strength of relationship

Some authors have also found that the correlation between customer engagement in creating value and the strength of the relationship is negative if customers do not feel satisfied and do not trust the brand (Akhter and Shrivastava, 2014).

\section{Relationship between Trust and Strength of the relationship}

Previous research has shown immutably that satisfaction and trust lead to building a strong bond between the customer and the company in order to create strong relationships (Rajah et al., 2008). Furthermore, research shows a strong correlation between co-creation and trust between the buyer and the seller: trust in its turn helps strengthen the buyer / seller relationship (Boyle, 2007; Mascarenhas et al., 2004; and Malaviya and Spargo, 2002). Moreover, Morgan and Hunt (1994) demonstrated that trust is a key factor in the development of buyer-seller relationship. It follows the fourth hypothesis.

- H4: Trust positively influences the strength of relationship between customer and buyer.

\section{Relationship between satisfaction and the strength of relationship}

The literature on the service quality satisfaction confirms that trust clarifies the strength of the customer-seller relationship (Claycomb and Martin, 2001; Storbacka et al., 1995). According to Fleming et al., (2003), satisfaction decreases the level of switching towards the company and increases the sense of belonging, which makes the relationship between the company and the customer stronger than before. In this context, we conclude that cocreation through the client's active participation, interaction and customization can affect customer satisfaction, trust, and create strong relationships between the company and the client. Hence the fifth hypothesis:

H5: Satisfaction has a positive effect on the relationship strength with the brand.

\section{Relationship between Strength of the relationship and Loyalty}

In the same vein, Auh et al., (2007) studied the co-production and its influence on the attitudes of loyalty and behavior. According to Evanschitzky et al., (2006), the strong relations between sellers and buyers reinforce customer loyalty. Therefore, this logic suggests that the solid relationship precedes customer loyalty and the strength of the relationship between the buyer and the seller will influence the degree of customer loyalty (Bove and Johnson, 2001; Hausman, 2001). In addition, it should be said that co-creation has great potential to create closer relationships with customers, which could lead to enhanced customer loyalty (Hoyer et al., 2010; Kambil et al., 1999). Therefore, the argument in this position proves the strength of the relationship of an antecedent to customer loyalty representing an important step from co-creation to achieving fidelity. As a result, the following hypothesis can be emitted:

- H6: The relationship strength positively affects consumer loyalty towards the brand.

\section{The Conceptual Model}

In summary, based on the above discussion, a conceptual model has been developed and has been devoted to determining the motivating factors involving the consumer in a Co-creation activity, and their indirect impact on the quality of the customer-brand relationship and loyalty. This model is represented below: 


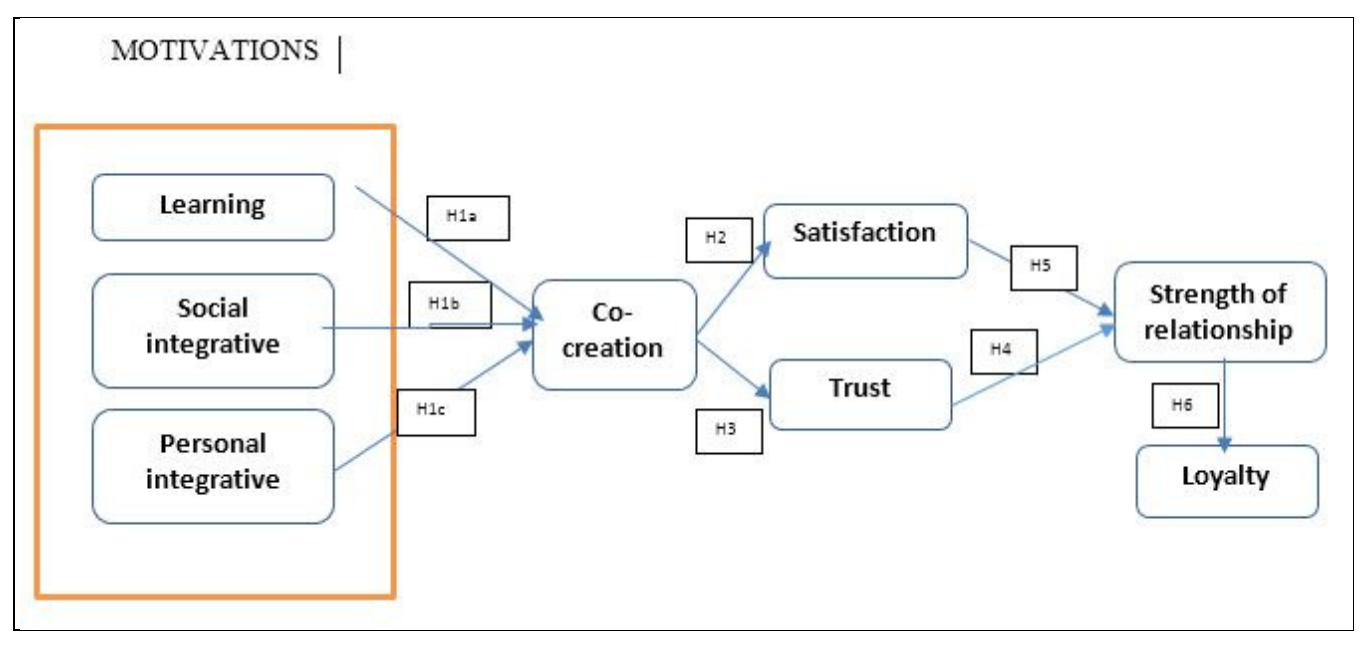

Figure 1: Conceptual framework

\section{Methodology}

\section{Measures}

The questionnaire consists of measurement scales borrowed from literature and each concept will be operationalized using a valid scale that will be brought back to the Tunisian context for the purposes of the study. All the measurement scales were adopted from the literature and adjusted to the research setting of co-creation. Therefore, pre-existing measuring scales were used. Three items were used for learning; these were adopted from Hoyer et al., (2010); Nambisan and Baron, (2007). The variable personal integration was measured with four items; this element was also adopted from Hoyer et al., (2010) and; Nambisan and Baron, (2007). Three items developed by Hoyer et al., (2010) were used to measure the social integration.

Three items were developed by Rajah et al., (2008) to measure co-creation. Satisfaction and Trust were measured with scales developed by (Prahalad, and Ramaswamy, 2003) constituted of three items each. To measure relationship strength, a scale with nine items by Rajah et al., (2008) was used. The brand loyalty variable consisted of two dimensions: attitudinal loyalty and behavioral loyalty which form the loyalty variable and it was measured with a scale with nine items as developed by Pritchard et al., (1999). All scales used in this study can be found in Appendix 1. All the items were measured using a five-graduation Likert scale. From (totally disagree=1 to totally agree $=5$ )

\section{Sample and data collection}

The target population for the study was customers who had an experience with cocreation. Sample selection was the result of convenient sampling. Data collection took two months. A questionnaire was developed and pre-tested with 30 customers $(10 \%$ of the sample). The questionnaire was adjusted following the various comments and suggestions. The administration of the final questionnaire was conducted through Google Drive online. This method is favorable and inexpensive, compared to other types of surveys

The final questionnaire was distributed to 405 users of our consumer product study, 360 usable responses were obtained (89\%) after excluding incomplete questionnaires. Users are divided between men and women aged 18 and older, knowing the Coca-Cola "chniatarbijtek" application, and participated in co-creating and customizing their soft drink bottle one week before the study. The Coca-Cola brand was chosen for this study because of its local as well as its international reputation on the market, and its previous experience in co-creation. 
Coca-Cola applied the co-creation in different ways through different names, respecting the uniqueness of each population. The co-creation approach used by Coca-Cola that we found in Tunisia is called: "ChniaTrabijtek?" or in English: "What is your nickname?" This initiative will be our study case.

\section{Analysis Method}

First, we have proceeded with an exploratory analysis (Spss.20) by using the Principal Component Analysis (PCA) that allows the researcher to examine the properties of the eight measuring instruments, and to reduce the number of items. This method is usually used when processing a large amount of data. Researchers recommend this method for a first purification item, to identify latent measures scales (Gerbing and Hamilton, 1997). Confirmatory factor analysis was used to assess the properties and the validity of the measurement model using AMOS 20. In order to measure the construct reliability and validity scales, Cronbach alpha scores were used to validate the measurement model and test its convergent and discriminant validity (Akrout, 2010).

\section{Results}

\section{Reliability and validity tests}

The dimensionality of the eight variables was examined, and the analysis showed that the scale of each concept has a onedimensional structure with sufficient KMO values (Kaiser-Meyer-Olkin) higher than 0,6 . In this analysis, the items whose communality was insufficient $(<0.5)$ were removed. The Cronbachs' alpha of each variable was greater than 0,7 . The results are presented in Table 1.

Table 1: Scales Reliabilities

\begin{tabular}{|c|c|c|c|c|c|c|c|}
\hline Scale & $\begin{array}{l}\text { Number } \\
\text { of Items }\end{array}$ & Dimentionality & KMO & $\begin{array}{c}\alpha \\
\text { Cronbach }\end{array}$ & \begin{tabular}{l}
\multicolumn{1}{c}{$\%$ of } \\
explained \\
variance
\end{tabular} & $\begin{array}{c}\text { Joreskog's } \\
\text { Rho }\end{array}$ & AVE \\
\hline Learning & 3 items & Unidimentional & 0.660 & 0.795 & 68.464 & 0,91 & 0,87 \\
\hline $\begin{array}{l}\text { Social } \\
\text { Integration }\end{array}$ & 3 items & Unidimentional & 0.658 & 0.781 & 69.751 & 0,84 & 0,78 \\
\hline $\begin{array}{l}\text { Personal } \\
\text { Integration }\end{array}$ & 3 items & Unidimentional & 0.821 & 0.702 & 74.151 & 0.85 & 0.81 \\
\hline Co-creation & 4 items & Unidimentional & 0.814 & 0.863 & 70.938 & 0,79 & 0,76 \\
\hline Satisfaction & 3 items & Unidimentional & 0.722 & 0.868 & 79.213 & 0,85 & 0,75 \\
\hline Trust & 3 items & Unidimentional & 0.730 & 0.848 & 76.926 & 0,87 & 0,82 \\
\hline $\begin{array}{l}\text { Strengh of } \\
\text { relationship }\end{array}$ & 6 items & Unidimentional & 0.873 & 0.893 & 65.366 & 0,74 & 0,72 \\
\hline Loyalty & 5 items & Unidimentional & 0.843 & 0.886 & 69.310 & 0,86 & 0,83 \\
\hline
\end{tabular}

To measure the reliability and validity of the scales, a confirmatory factor analysis was performed using the SEM method with AMOS 20. Based on the measurement model, the Joreskog's Rho was used in order to measure the reliability and the internal consistency of each scale (Akrout, 2010). The reliability of the measures of all eight variables was confirmed as all the indices of Joreskog's Rho are above 0,7 , which is the limit set by Bagozzi and Phillips (1982). The reliability is a necessary, but not sufficient condition for the validity of a measure (see Table 1). Therefore, the study first tested the convergent validity by the average variance extracted from the constructs, which is, in this study, satisfactory with values over 0.7 (Akrout, 2010; Fornell and Larcker, 1981; Houston and Rothschild, 1987). Second, to determine the discriminant validity of the overall model, we use the approach of Fornell and Larker (1981). This question is to ensure that the average variance extracted PVC (calculated for the evaluation of convergent validity) exceeds 
the square of correlations between latent variables. The following table summarizes the results of this comparison.

Table 2: Discriminant Validity Results

\begin{tabular}{|c|c|c|c|c|c|c|c|c|c|c|}
\hline & $\begin{array}{l}\text { Convergent } \\
\text { Validity } \\
\text { (Joreskog's } \\
\text { Rho) }\end{array}$ & $\begin{array}{l}\text { Persona } \\
1 \\
\text { integrati } \\
\text { on }\end{array}$ & $\begin{array}{l}\text { Social } \\
\text { integratio } \\
n\end{array}$ & $\begin{array}{l}\text { Learnin } \\
\mathrm{g}\end{array}$ & $\begin{array}{l}\text { Co- } \\
\text { creatio } \\
n\end{array}$ & Trust & $\begin{array}{l}\text { satisf } \\
\text { actio } \\
n\end{array}$ & & $\begin{array}{l}\text { rengh } \\
\text { lations } \\
\text { p }\end{array}$ & $\begin{array}{l}\text { Loyalt } \\
\mathrm{y}\end{array}$ \\
\hline $\begin{array}{l}\text { Personal } \\
\text { integration }\end{array}$ & 0,91 & 1 & & & & & & & & \\
\hline Social integration & 0,84 & 0,623 & 1 & & & & & & & \\
\hline Learning & 0.85 & 0,438 & 0,270 & 1 & & & & & & \\
\hline Co-creation & 0,79 & 0,608 & 0,557 & 0,258 & 1 & & & & & \\
\hline Trust & 0,85 & 0,442 & 0,404 & 0,187 & 0,726 & 1 & & & & \\
\hline Satisfaction & 0,87 & 0,387 & 0,353 & 0,164 & 0,634 & 0,461 & & 1 & & \\
\hline $\begin{array}{l}\text { Strengh of } \\
\text { relationship }\end{array}$ & 0,74 & 0,423 & 0,387 & 0,179 & 0,694 & 0,731 & 0,6 & & 1 & \\
\hline Loyalty & 0,86 & 0,352 & 0,321 & 0,149 & 0,578 & 0,642 & 0,5 & & 0,832 & 1 \\
\hline
\end{tabular}

The discriminant validity results show that the average variance extracted PVC (calculated for the evaluation of convergent validity) exceeds the square of correlations between latent variables. Our model appears therefore parsimonious.

\section{The fit of the conceptual model}

The fit indicators were measured in order to assess how the model studied fits in relation to the theoretical model. The results provided satisfactory support for the eight dimensional model with $\mathrm{Chi} 2 / \mathrm{df}=$ $3,143(<5)$, with values of GFI $(0,8)$, AGFI $(0,904)$, CFI $(0,9)$ and FI $(0,88)$ which tend to 1 , and RMSEA=0,077 $(<0,1)$ (Figure 2). Thus, the model was found to be acceptable.

MOTIVATIONS

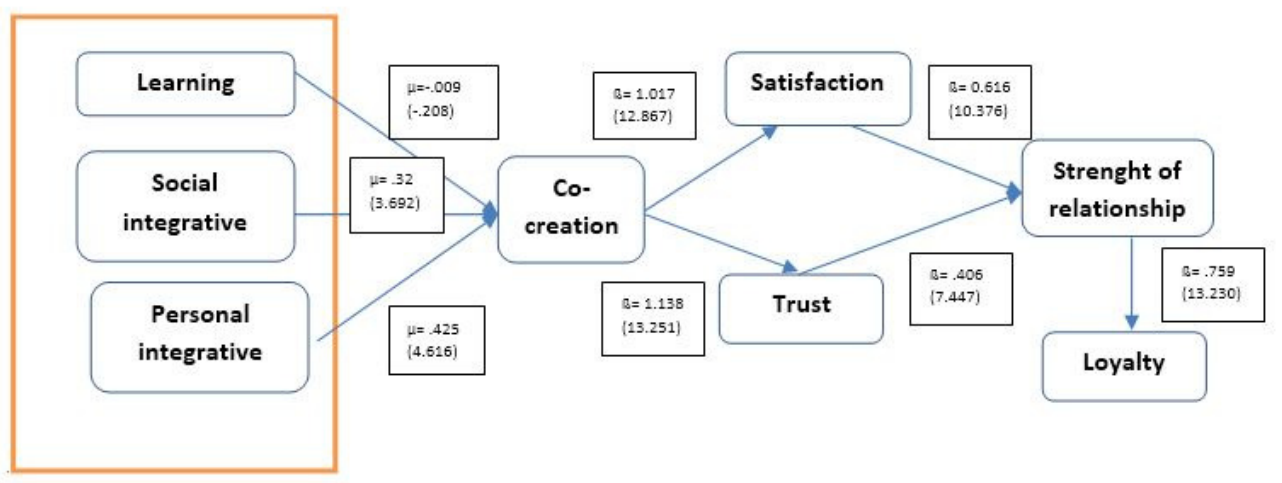

Figure 2:Results of structural model 


\section{Hypothesis testing}

The results (Tab 3) showed that the relationship between the cognitive aspect (learning) and co-creation was rejected. The effect is, however, less significant and negative (estimate $=-0.009$, $\mathrm{t}$-value $=-0.208$, $\mathrm{p}=0.835$ ). Therefore, H1a was not retained. The second hypothesis $\mathrm{H} 1 \mathrm{~b}$, which stipulates that the social integration affects positively the co-creation, was confirmed and with a strong positive coefficient (estimate $=0.302, \mathrm{t}$-value $=$ $369.2, p=0.000$ ). The direct effect between social integration and co-creation was also confirmed (estimate $=0.302, \mathrm{t}=3.692, \mathrm{p}=$ $0.00)$. The third hypothesis H1c showed that the personal integration benefits have a significant and positive impact on the cocreation. The test was significant with a strong positive coefficient (estimate $=$ $0,425, \mathrm{t}$-value $=4,616, \mathrm{p}=0,000)$. So, consequently the $\mathrm{H} 1 \mathrm{c}$ was confirmed. The $\mathrm{H} 2$ hypothesis, which stipulates that the cocreation has a positive effect on customer satisfaction, was confirmed with a strong positive coefficient (estimate $=1,017, \mathrm{t}-$ value $=12,867$ and $p=0.000$ ). In the same way, the results of the $\mathrm{H} 3$ hypothesis showed that co-creation positively influences the level of trust with the customer with a strong positive coefficient (estimate $=1,138$; $t$-value $=13,251$ and $p=$ 0.000). Furthermore, the $\mathrm{H} 4$ hypothesis which stipulates that the satisfaction has a positive effect on the strength of relationship was confirmed with a strong positive coefficient (estimate $=0,616, \mathrm{t}$ value $=10,376, p=0.000$ ). Further, the results of $\mathrm{H} 5$ hypothesis have showed that Trust influences positively and deeply the strength of relationship (estimate $=0,406, \mathrm{t}$ value $=7,447$ and $p=0.000$ ). Finally, the $\mathrm{H} 6$ hypothesis, which stipulates that the strength of the relationship affects positively the customer loyalty, has also been confirmed with a strong positive coefficient (estimate $=0,759, \quad \mathrm{t}$-value =13,230, and $\mathrm{p}=0.000$ ).

Table 3: Hypothesis results

\begin{tabular}{|c|c|c|c|c|}
\hline Hypothesis & Estimate & C.R & $\mathrm{Pv}$ & Results \\
\hline $\begin{array}{|lll|}\text { Co-creation } & \text { Learning } \\
\end{array}$ & $-0,009$ & $-0,208$ & 835 & Rejected \\
\hline 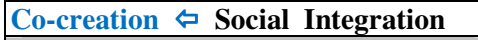 & 0.302 & 3,692 & $* * *$ & Confirmed \\
\hline \begin{tabular}{|c|c|} 
Co-creation $\diamond$ personal Integration \\
\end{tabular} &, 425 & 4,616 & $* * *$ & Confirmed \\
\hline \begin{tabular}{|l|} 
satisfaction $\diamond$ Co-creation \\
\end{tabular} & 1,017 & 12,867 & $* * *$ & Confirmed \\
\hline Trust $\quad$ Co-creation & 1,138 & 13,251 & $* * *$ & Confirmed \\
\hline $\begin{array}{l}\text { Strenght of relationship } \\
\text { Satisfaction }\end{array}$ & 0,616 & 10,376 & $* * *$ & Confirmed \\
\hline Strenght of relationship $\diamond$ Trust & 0,406 & 7,447 & $* * *$ & Confirmed \\
\hline Loyalty $\diamond$ Strengh of relationship & 0,759 & 13,230 & $* * *$ & Confirmed \\
\hline
\end{tabular}

\section{Discussion and Conclusion}

This research was dedicated to the identification of motivational factors leading to the involvement of the consumer in a co-creation activity, by stressing the impact of the latter on the quality of the client-brand relationship and his degree of loyalty.

We succeeded to demonstrate the impact of the motivational factors (U\&G approach) on the consumer's responses vis-a-vis the co-creation. This relationship, which was less tested in the literature, has been confirmed empirically and has added to the proposal made by (Hoyer et al., 2010) in their conceptual model.

In consequence, the research confirms that the online co-creation between the producer of Coca Cola and the Internet users on social media influences positively the consumers' satisfaction. This positive relation influences, consequently, the strength of the relationship between the consumer and the brand, and therefore converges with (Rajah et al., 2012), Dong 
(2007), Leadbeater (2006) and Boyle (2007) studies' results. Finally, we have come to estimate the effects of the strength of the relationship on the consumer's loyalty and to reinforce the results of the previous research of Evanchitzky, (2006); Zerbini et al., (2007), Auh et al., (2007). At the end of these empirical tests, we validated a model that showed schematically the direct consequences of co-creation. The results coincided with previous research of Rajah et al., (2012), Hoyer et al., (2010). Similarly, social and personal contexts in our study have a direct impact on co-creation, which in their turn disclose a positive influence on the consumer satisfaction (Bendapudi and Leone, 2003) and trust (Leadbeater, 2006; Evans and Wolf, 2005; Lundkvist and Yaklef 2004; Mascarenhas et al., 2004; Malaviya and Spargo, 2002). This promotes the strength of customer-brand relationship and positively enhances and contributes to reinforcing the consumers' loyalty toward the brand and product (Evanschitzky et al., 2006).

However, learning's effect on co-creation is absent in the context of this study, which diverges with the literature yet can be explained by the choice of the selected industrial brand (Coca-Cola). We can advance that the consumers benefits achieved through their participation in the co-creation experience are related to the social and personal integration in the virtual community, far from the learning attitude. This behavior is affected by the variables that affect perception vis-à-vis the product implication.

\section{Research contributions, limitations and future pathways}

As part of this research, it is legitimate to ask about its contributions, at both theoretical and managerial level.

\section{Theoretical and managerial Contributions}

This study has enriched the knowledge of this new concept of co-creation (Rajah et al., 2008; Romero et al., 2014). This work has also helped to integrate an old concept, the one of loyalty, in the study of a new tool for online co-creation and its indirect impact.

In fact, literature, allowed us to understand how to create value, and accurately understand the act of the online co-creation with the producer to broadcasted different stimuli. Hence, this pushed us to address the concept of co-creation and its relationship with the motivational factors that led the Internet user to co-create, and study the causal relationship with the benefits of the brand, trust and satisfaction. These relationships, upstreaming and down streaming co-creation, allow us to identify the different types of benefits, both for the customers and the brand. Although the concept of co-creation, or rather of "value creation", has been the subject of several studies in various fields, it has never been used in the field of web 3.0, nor has it been used in particular to describe the association between motivation and cocreation itself. Additionally, our work is the first marketing using the methodology of dynamic panel logistics. Furthermore, our research is listed as the first work that has successfully confirmed the existence of a direct link or relationship between the $U$ \& $G$ approach and co-creation. Moreover, following this study, we can confirm all assumptions and highlight the effect of co creation on the strength of the relationship, which in its turn influences loyalty. Finally, this work has helped to highlight the importance of co-creating online brands in the Tunisian context and especially in the context of Web 3.0. Similarly, our results are to help enrich the research on the subject by focusing on a specific case of cocreation experience, namely mass customization (Cova, 2008).

When talking about managerial contribution, this study allows some operational observations. These include the importance of strategic consequences from participation in a virtual co-creation activity online, that gives to the consumer a sense of belonging to the brand. In other words, the user identifies with the brand, which triggers a positive attitude and behavioral loyalty. It is also essential to emphasize the relational importance felt after participating in a virtual activity of co- 
creation, with the important role of trust and satisfaction attributed to the Internet user. It also stresses the way in which we can create common value between the customer and the brand and how to keep this relational quality (loyalty). This means that great importance should be given to web 3.0 marketing as an essential tool for co-creation, yet it can and should also be used in other Tunisian contexts. Thus, the inclusion of these variables in determining the effect of co-creation enriches the analytical framework in the industrial sector and consumer products.

\section{Research limitations}

The sampling technique adopted is that of a sampling by convenience. Only one exchange context, namely "chniatarbijtik" Coca Cola in Tunisia, was studied. The model could be tested in two different contexts to generalize the results. Finally, the scale of Co-Creation was created only recently by Rajah et al., (2008). This is an orphan variable of marketing studies and there is a shortage of literature in this area.

\section{Future pathways of the research}

It follows from all the foregoing, some future pathways of research:

- A qualitative study with Cocreators online allows us to deeply understand the why of the behavior and its root causes through the recovery of rich, deep and variable data.

- $\quad$ To test the same model with other people online with any products or services, at both the national and international level.

- To conduct the same survey with a sampling stratum.

- To conduct the same survey with a larger sample.

- To include the instruments of mediation variables, i.e. the costs of switching and affective commitment.

\section{References}

1. Abidi-Barthe.A, and Kaabachi,S. (2010). 'La co-création d'expériences de consommation par le Web2.0'. Journal of Internet Banking and Commerce, 15(2).

2. Akrout, F. (2010). " Les Méthodes Des Équations Structurelles ». 1ère Edition, 273 Pages.

3. Algesheimer, R., Dholakia, U.M., and Herman, A. (2005). "The social influence of brand community: Evidence from European car clubs'. Journal of Marketing, 69, 19-34.

4. Auh, S., Bell, S. J., McLeod, C. S., and Shih, E. (2007). 'Co-production and Customer Loyalty in Financial Services'. Journal of Retailing, 83, 359370.

5. Badot O., and Cova, B. (1995). 'Communauté et consommation : prospective pour un marketing tribal'. Revue française du marketing, 151, 5-17.

6. Barnes J, G., Howlett, D.M. (1998). 'Predictors of equity in relationships between financial services providers and retail customers'. International Journal Bank Marketing, 16(1), 15-23.

7. Bendapudi, N., and Berry, L, L. (1997). 'customers motivations for maintaining relationships with service providers'. Journal of retailing, 73, 15-37.

8. Bendapudi, N., and Leone, R. P. (2003). 'Psychological implications of customer participation in co-production'. Journal of Marketing, 67(1), 14-28.

9. Bove LL., and Johnson LW. (2006). 'Customer loyalty to one service worker: should it be discouraged?'. International Journal of Research in Marketing, 23(1), 79-91.

10. Boyle, E. (2007). 'A process model of brand cocreation: Brand management and research implications'. Journal of Product and Brand Management, 16(2), 122-131.

11. Claycomb, C., and Martin, C. L. (2001). 'Building customer relationships: An inventory of service providers' objectives and practices'. Marketing Intelligence and Planning, 19(6), 385399.

12. Cortizo, J. (2011). 'Introduction to the Special Issue: Mining Social Media'. 
International Journal of Electronic Commerce, 15(3), 5-8.

13. Cova, B. (2008). 'Consumer made : quand je consommateur devient producteur'. Decisions Marketing, 50, 19-27.

14. Crosby, LA., Evans, KR., and Cowles, D. (1990). 'Relationship quality in services selling: an interpersonal influence perspective'. Journal of Marketing, 54(3), 68-81.

15. Crosby, LA., and Stephens, N. (1987). 'Effects of relationship marketing on satisfaction retention, and prices in the life insurance industry'. Journal Marketing Resource, 24(4), 404-11.

16. Csikszentmihalyi, M. (1996). 'Creativity: Flow and the Psychology of Discovery and Invention'. New York, NY: Harper Collins.

17. Czepiel, JA. (1990). 'Service encounters and service relationships: implications for research'. Journal Business Research, 20(1), 13-21.

18. Delgado-Ballester, E., and Munuera-Aleman, J. (2001). 'Brand Trust in the Context of Consumer Loyalty'. European Journal of Marketing, 35(11/12), 1238-1258.

19. Dong, B., Evans, K. R., and Zou, S. (2008) 'The Effects of Customer Participation in CoCreated Service Recovery'. Journal of the Academy of Marketing Science, 36, 123-137.

20. Doorn.V, Jenny, K, N., ,Mittal.,V., Naß.S , Pick.D, Pirner, P. and Verhoef, P. (2010).'Customer Engagement Behavior: Theoretical Foundations and Research Directions'. Journal of Service Research, 13 (3), 253-266.

21. Dwyer, F. R., and Tanner, J. F. (2006). 'Business marketing: Connecting strategy, relationships and learning' (Third Edition ed.). New York: McGraw-Hill Irwin.

22. Egan, J. (2001). 'Relationship Marketing: Exploring Relational Strategies in Marketing'. Financial

23. Times Prentice Hall, Harlow.

24. Etgar, M. (2008). 'A Descriptive Model of the Consumer Co-Production Process'. Journal of the Academy of Marketing Science, 36 (Spring), 97108.

25. Evans, P., and Wolf, B. (2005). 'Collaboration rules'. Harvard Business Review, 83, 95-104.
26. Evanschitzky, H., Iyer, G. R., Plassman, H., Niessing, J., and Meffert, H. (2006). 'The relative strength of affective commitment in securing loyalty in service relationships'. Journal of Business Research, 59, 1207-1213.

27. Fleming, J. H., Coffman, C., and Harter, J. K. (2005). 'Manage your human sigma'. Harvard Business Review (July / August), 107-114.

28. Füller, J. (2010). 'Refining Virtual Co-Creation from a Consumer Perspective'. California Management Review, 52(2), 98-122.

29. Füller, J., Faullant, R., and Matzler, K. (2010). 'Triggers for virtual customer integration in the development of medical equipment - From a manufacturer and a user's perspective'. Industrial Marketing Management, 39(8), 13761383.

30. Fullerton, G. (2003). 'When Does Commitment Lead to Loyalty?'. Journal of Service Research, 5(4), 333-344.

31. Granovetter MS. (1973). 'The strength of weak ties'. American Journal Sociology, 78(6), 1360-79.

32. Grissemann, U. S., and Stokburger-Sauer, N. E. (2012). 'Customer Co-Creation of Travel Services: The Role of Company Support and Customer Satisfaction with the Co-Creation Performance'. Tourism Management, 33, 14831492.

33. Gro"nroos, C. (2008). 'Service Logic Revisited: Who Creates Value? And Who CoCreates?'. European Business Review, 20(4), 298-314.

34. Grönroos, C. (2011). 'Value co-creation in service logic: A critical analysis'. Marketing Theory, 11(3), 279-301.

35. Hausman, A. (2001). 'Variations in relationship strength and its impact upon performance and satisfaction in business relationships'. Journal of Industrial and Business Marketing, 16(6/7), 600-616.

36. Heitmann, M., Lehmann, D. R., and Herrmann, A. (2007). 'Choice goal attainment and decision and consumption satisfaction'. Journal of Marketing Research, 44(2), 234-250.

37. Heitmann. M, lehmann, D, R., and herrmann.A (2007). 'Choice Goal Attainment and Decision and Consumption Satisfaction'. Journal of Marketing Research, 234-250.

38. Hoyer, W. D., Chandy, R., Dorotic, M., Krafft, M., and Singh, S. S. (2010). 'Consumer co- 
creation in new product development'. Journal of Service Research, 13(3), 283-296.

39. Jackson, BB. (1985). 'Build customer relationships that last'. Harvard Business Review, 63 (6), 120-8.

40. Jarvenpaa, S.L., Knoll, K., and Leidner, D.E. (1998). 'Is there anybody out there? Antecedents of trust in global virtual teams'. Journal of Management Information Systems, 14 (4), 29-64.

41. Javaid.A and Priyanka.S. (2014). 'Empirical study on strategic application of co-creation process: a conceptual framework to effectively collaborate with customers'. International journal of engineering and management sciences, 5 (2) 2014, 146-154.

42. Jeppesen, L. B and Lakhani, K. R. (2010). 'Marginality and Problem-Solving Effectiveness in Broadcast Search'. Organization Science, 21(5), 1016-1033.

43. Jöreskog K., and Sörbom D. (1982). 'Recent developments in structural equation modeling'. Journal of marketing research, 19, 404-416.

44. Joshi, A, W., and Sharma, S. (2004). 'Customer Knowledge Development: Antecedents and Impact on New Product Performance'. Journal of Marketing, 68 (3), 47 59.

45. Kandampully J., and Duddy R. (1999). 'Relationship marketing: a concept beyond the primary relationships'. Marketing Intelligent Planning, 17(7), 315-23.

46. Kietzmann, J. H.. K. Hermkens, I. P.McCarthy, B. S. (2011). 'Social media? Get serious! Understanding the functional building blocks of social media'. Business Horizons, 54(3), 241-251.

47. Kotze, T. G., and Plessis, P. J. (2003). 'Students as "co-producers" of education: A proposed model of student socialisation and participation at tertiary institutions'. Quality Assurance in Education, 11(4), 186-201.

48. Kumar, V., Aksoy.L, Donkers.B, Wiesel.T, Venkatesan.R, and Tillmanns.S. (2010). 'Undervalued or Overvalued Customers: Capturing Total Customer Engagement Value'. Journal of Service Research, 13 (August), 297310.

49. Leadbeater, C. (2006). 'The user innovation revolution'. London: National Consumer Council. Retrieved from www.ncc.org.uk
50. Liljander V. (2000). "The importance of internal relationship marketing for external relationship success'.Hennig-Thurau T., Hansen, U., editors. 'Relationship marketing: gaining competitive advantage through customer satisfaction and customer retention'. Berlin: Springer; (2000), 161-92.

51. Lorenzo-Romeroa.C, Constantinides, b. E., and Leonine A. B. (2014). 'Co-Creation: Customer Integration in Social Media Based Product and Service Development'. Procedia Social and Behavioral Sciences, 148(2), 383 396.

52. Lundkvist, A., and Yaklef, A. (2004). 'Customer involvement in new service development: A conversational approach'. Managing Service Quality, 14(2/3), 249-257.

53. Luo, X. (2002). 'Uses and gratifications theory and e-consumer behaviors: A structural equation modeling study'. Journal of Interactive Advertising, 2(2), 34-41.

54. Malaviya, P., and Spargo, S. (2002). 'Relating to customers: How and when to strengthen your customer relationships' (2002/41/MKT). Fontainebleau.

55. Mascarenhas, O. A., Kesavan, R., and Bernaccchi, M. (2004). 'Customer value chain involvement for co-creating customer delight'. Journal of Consumer Marketing, 21(7), 486496.

56. Meziou, R. (2010). 'L'impact du parrainage télévisuel sur les réponses des consommateurs : rôle de la congruence entre une émission et un parrain, thèse de doctorat en science de gestion', Faculté des sciences économiques et de gestion de Tunis et l'Université Jean Moulin Lyon 3.

57. Mills, P, K., Richard B. C., and Margulies, N. (1983). 'Motivating the Client/Employee System as a Service Production Strategy'. The Academy of Management Review, 8 (2), 301-310.

58. Minkiewicz, J., Evans, J., and Bridson, K. (2014). 'How do consumers co-create their experiences? An exploration in the heritage sector'. Journal of Marketing Management, 30(12), 30-59.

59. Morgan, R. M., and Hunt, S. D. (1994). 'The committment-trust theory of relationship marketing'. Journal of Marketing, 14(4), 374395.

60. Morin, (1983). P these (university of Orsay).

61. Mun iz, A, M., Jr. and Schau, H,J. (2005). 'Religiosity in the Abandoned Apple Newton 
Brand Community'. Journal of Consumer Research 31 (March), 737-747.

62. Muñiz, A., and O'Guinn, T. (2001). 'Brand community'. Journal of Consumer Research, 27(4), pp. 412-32.

63. Nambisan, S. (2002). 'Designing Virtual Customer Environments for New Product Development: Toward a Theory'. Academy of Management Review, 27 (3): 392-413.

64. Nambisan, S., and Baron, R. A. (2007). 'Customer environments: Relationship management'. Journal of Interactive Marketing, 21(2), 42-62.

65. Nambisan, S., and Baron, R. A. (2007). 'Interactions in virtual customer environments: Implications for product support and customer relationship management'. Journal of Interactive Marketing, 21 (2), 42-62.

66. Nambisan, S., and Baron,A, R. (2009). 'Virtual Customer Environments: Testing a Model of Voluntary Participation in Value Co-creation Activities'. The Journal of Product Innovation Management, 26 (4), 388-406.

67. Neuhofer, B., and Buhalis, D. (2013). 'Experience, Co-Creation and Technology Challenges and Trends for Technology Enhanced Tourism Experiences'. Handbook of Tourism Marketing. London, 124-139.

68. Luo., N., Zhang, M., and Liu, W. (2015). 'The effects of value co-creation practices on building harmonious brand community and achieving brand loyalty on social media in China'. Computers in Human Behavior, 48, 492-499.

69. O'Hern, M, S., and Rindfleisch, A. (2009) 'Customer Co-Creation: A Typology and Research Agenda'. Review of Marketing Research, 6, 84-106.

70. Ogawa, S., and Piller, F.T. (2006). 'Reducing the Risks of New Product Development'. Sloan Management Review, 47 (Winter), 65-72.

71. Payne, A., Storbacka, K., Frow, P., and Simon, K. (2009). 'Co-creating brands: Diagnosing and designing the relationship experience'. Journal of Business Research, 62, 379-389.

72. Payne, A, F., Storbacka.k, and Frow.P. (2008) 'Managing the Co-creation of Value'. Journal of the Academy of Marketing Science, 36 (1), 83-96.

73. Prahalad, C. K. and Ramaswamy.V. (2000). 'Co-opting Customer Competence'. Harvard Business Review, 78 (January-February), 79-87.
74. Prahalad, C. K., and Ramaswamy, V. (2003). 'The new frontier of experience innovation'. Management Review, 44(4), 12.

75. Prahalad, C.K., and Ramaswamy, V., (2004). 'The future of competition: co-creating unique value with customers'. Boston, MA: Harvard Business School Press.

76. Pritchard, M., Havitz, M., and Howard, D. (1999). 'Analyzing the Commitment-Loyalty Link in Service Relationships'. Journal of the Academy of Marketing Science, 27(3),333-48.

77. Rajah E., Marshall R., Nam, I. (2008). 'Relationship Glue: Customers and Marketers Co-Creating a Purchase Experience'. Advances in Consumer Research, 35, 367-373.

78. Rajah. E, (2012). 'Modelling Co-creation and its Consequences: One Step'

79. Ramaswamy, V. (2009). 'Leading the transformation to co-creation of value'. Strategy \& Leadership, 37 (2), 32-37.

80. Romero, D., and Molina, A. (2011). 'Collaborative networked organisations and customer communities: value co-creation and co-innovation in the networking era'. Production Planning and Control: The Management of Operations, 22(5-6), 447-472.

81. Sahwney, M., Verona, G., and Prandelli, E. (2005). 'Collaborating to create: The internet as a platform for customer engagement in product innovation'. Journal of Interactive Marketing, 19(4), 4-34.

82. Sanders E. B.-N., and Stappers, P.J. (2008). 'Co-creation and the new landscapes of design'. CoDesign, 4(1), 5-18.

83. Sawhney, M., and Prandelli, E. (2000). 'Communities of creation: Managing distributed innovation in turbulent markets'. California Management Review, 42(4), 24-54.

84. Selnes, F. (1998). 'Antecedents and consequences of trust and satisfaction in buyerseller relationships'. European Journal of Marketing, 32(3/4), 305-322.

85. Sharma, A., and Seth, J .N. (2004). 'Webbased marketing: The coming revolution in marketing thought and strategy'. Journal of Business Research, 57 (7), 696-702.

86. Shemwell, DJ., and Cronin, JJ., (1995). 'Trust and commitment in customer/service-provider relationships: an analysis of differences across service types and between sexes'. Journal Customer Service Marketing and Management, $1(2), 65-75$. 
87. Storbacka, K., Strandvik, T., and Groonroos, C. (1995). 'Managing customer relationships for profits: The dynamics of relationship quality'. International Journal of Service Industry Management, 5(5), 21-38.

88. Urista, M. A., Dong, Q., and Day, K. D. (2008). 'Explaining Why Young Adults Use MySpace and Facebook Trough Uses and Gratification Theory'. Human Communication. A Publication of the Pacific and Asian Communication Association, 12(2), 215-229.

89. Vargo, S. L., Maglio, P. P., and Akaka, M. A. (2008). 'On Value and Value Co-Creation: A Service Systems and Service Logic Perspective'. European Management Journal, 26, 145-152.
90. Vernette.E., Hamdi-Kidar.L. (2010). 'Leaduser ou consommateur de nature émergente ? Une recherche de paternité pour les stratégies de co-création marketing'. Centre de Recherche en Management, UMR 5303, France 21, 1-21.

91. Williams D. (1997). 'Employee relations'. Business Economic Review, 43(4), 8-11.

92. Zineldin M. (1999). 'Exploring the common ground of total relationship management (TRM) and total quality management (TQM)'. Management Decision, 37(9),719-28.

93. Zwick, D., Bonsu, S.K. and Darmody, A.+(2008). 'Putting consumers to work: "Cocreation" and new marketing govern-mentality'. Journal of Consumer Culture, 8(2), 163- 196.

\section{Appendix}

\section{Items}

\begin{tabular}{|c|c|}
\hline Variables & items \\
\hline $\begin{array}{l}\text { Social Integrative } \\
\text { Hoyer et al., 2010); } \\
\text { (Nambisan and Baron, } \\
\text { 2007). }\end{array}$ & $\begin{array}{l}\text { - I participate in online co-creation activities when they expand } \\
\text { my personal network. } \\
\text { - I participate in online co-creation activities when they raise my } \\
\text { status/ reputation as product expert in my personal network. } \\
\text { - I participate in online co-creation activities when they enhance } \\
\text { my strength of my affiliation with the customer community. }\end{array}$ \\
\hline $\begin{array}{l}\text { Learning } \\
\text { Nambisan and Baron, } \\
\text { 2007); (Nambisan and } \\
\text { Baron, 2009) }\end{array}$ & $\begin{array}{l}\text { - I participate in online co-creation activities when they enhance } \\
\text { my knowledge about the product and its usage. } \\
\text { - I participate in online co-creation activities when they enhance } \\
\text { my knowledge on product trends, related products and } \\
\text { technology. } \\
\text { - I participate in online co-creation activities when they help me } \\
\text { make better product decisions as consumer. }\end{array}$ \\
\hline $\begin{array}{l}\text { Personal Integrative } \\
\text { Nambisan and Baron, } \\
\text { 2007); (Nambisan and } \\
\text { Baron, 2009) }\end{array}$ & $\begin{array}{l}\text { - I participate in online co-creation activities when they are likely } \\
\text { to positively affect my professional career. } \\
\text { - I participate in online co-creation activities when they offer me } \\
\text { satisfaction from influencing product design and development. } \\
\text { - I participate in online co-creation activities when they offer me } \\
\text { satisfaction from influencing product usage by other customers. }\end{array}$ \\
\hline $\begin{array}{l}\text { Co-creation (Rajah et al., } \\
2008)\end{array}$ & $\begin{array}{l}\text { - The brand went out of its way to work with me } \\
\text { - I contributed actively to my final customer solution } \\
\text { - My final marketing solution was arrived through the joint efforts } \\
\text { of the brand and me } \\
\text { - It did not matter whether the customer participated in the } \\
\text { marketing transaction, the company would have been able to } \\
\text { deliver the same final solution } \\
\text { - My final customer solution evolved from the active participation } \\
\text { of the brand and me } \\
\text { - Overall, I would describe my final customer solution as a high } \\
\text { level of co-creation }\end{array}$ \\
\hline $\begin{array}{l}\text { Strength of } \\
\text { Relationship: } \\
\text { (Rajah et al., 2008) }\end{array}$ & $\begin{array}{l}\text {-I got a good price deal from the brand } \\
\text {-The (travel agency) has good pricing for its product offerings } \\
\text { - I like my interactions I have with the brand }\end{array}$ \\
\hline
\end{tabular}

Nedra Bahri Ammari and Emna Jaziri (2016), Journal of Marketing Research and Case Studies, 


\begin{tabular}{|l|l|}
\hline & $\begin{array}{l}\text { - The travel agency makes a strong effort to get to know me } \\
\text {-The brand is flexible and adaptable in its marketing approach to } \\
\text { the customer } \\
\text {-I am willing to share to share information and knowledge with } \\
\text { the brand } \\
\text {-My relationship to this specific brand is strong } \\
\text { - My relationship to this specific brand is important to me } \\
\text {-My relationship to this specific brand is something I care about }\end{array}$ \\
\hline $\begin{array}{l}\text { Trust (Prahalad and } \\
\text { Ramaswamy 2003) }\end{array}$ & $\begin{array}{l}\text {-In our relationship, the brand can be counted to do what is right } \\
\text { - In our relationship, the brand has high integrity } \\
\text { - In our relationship, the brand can be trusted at all times }\end{array}$ \\
\hline $\begin{array}{l}\text { Satisfaction (Prahalad } \\
\text { and Ramaswamy, 2003) }\end{array}$ & $\begin{array}{l}\text { - I think I did the right thing when I chose brand - The service } \\
\text { offerings of this brand meet my expectations } \\
\text { - Overall, I am pleased with the services offerings of this brand }\end{array}$ \\
\hline $\begin{array}{l}\text { Loyalty } \\
\text { (Pritchard et al., 1999); } \\
\text { (Swanson and Kelley, } \\
\text { 2001) }\end{array}$ & $\begin{array}{l}\text { - I consider myself to be a loyal patron of this brand - If I had to } \\
\text { do it all over again, I would do business with this brand } \\
\text { - I use this brand because it is the best choice for me } \\
\text { - This brand is distinct from other brands } \\
\text { - To me XYX is the same as other brand } \\
\text { - If I had a choice, I would use this brand again } \\
\text { - I am likely to go back to this brand the next time I need products } \\
\text { or services } \\
\text { - I am likely to repurchase from this travel agency in the future } \\
\text { - I am not likely to switch to another brand }\end{array}$ \\
\hline
\end{tabular}

A part of this work was presented at the Proceeding of the Marketing Spring Colloquy (MSC), the 7th Conference of URAM Unit of Research \& Applications in Marketing (URAM) Volume: 7. May, 2016. P: 74-83, Hammamet, Tunisia, 20-21 May, 2016. 